\title{
CREATIVE ACCOUNTING PRACTICE: CURSE OR BLESSING - A PERCEPTION GAP ANALYSIS AMONG AUDITORS AND ACCOUNTANTS OF LISTED COMPANIES IN BANGLADESH
}

Asif Mahbub Karim
Associate Professor
Chairman, Department of Business
Administration
Port City International University, Chittagong,
Bangladesh

\begin{tabular}{|c|c|}
\hline Dr. Junaid M Shaikh & Md. Rafiqul Islam \\
Professor & Lecturer \\
School of Business & $\begin{array}{c}\text { Faculty of Business Administration } \\
\text { BGC Trust University Bangladesh } \\
\text { Chittagong, Bangladesh }\end{array}$ \\
\hline
\end{tabular}

\section{ABSTRACT}

Creative Accounting also known as Hollywood accounting, income smoothing, cosmetic accounting is a legitimate accounting application where by the accountants and the auditors take advantage of the loopholes in the accounting policies as per International Accounting Standards (IAS), Generally Accepted Accounting Principles (GAAP). This research is conducted on the empirical data collected from the auditors and the accountants of the listed companies of Bangladesh who are the members of the Institute of Chartered Accountants of Bangladesh (ICAB) the professional accounting body in Bangladesh. They were interviewed using a 5 point Likert scale questionnaire and the responses were analyzed. A total 50 Auditors were surveyed from listed companies and 100 Accountants was surveyed from listed companies as respondents as to form an opinion at national level and have a meaningful contribution.

Keywords: Creative Accounting, International Accounting Standard, Window Dressing.

\section{Introduction}

Study of Perception of Creative Accounting Techniques and Applications in Bangladesh perspective, here the main objective is to investigate the gap analysis as well between the perception of auditors and the accountants in relation to creative accounting technique and application. In 


\section{ELK ASIA PACIFIC JOURNAL OF FINANCE AND RISK MANAGEMENT}

ISSN 2349-2325 (Online); DOI: 10.16962/EAPJFRM/issn. 2349-2325/2015; Volume 6 Issue 4 (2015)

all financial audit carried out by the external auditors representing the audit firms it is the norm to see that the financial statements are reflecting a true and fair view and this must be presented to the shareholders in the form of unqualified audit report as per Company's Act 1994. The Company's Act 1994 says that at every Annual General Meeting (AGM) the shareholders will appoint or re appoint the auditor or auditors and the auditors will take up the office for the next financial year. According to Smith (1992) "considers that the highest part of the economic growth of the ' $80 \mathrm{~s}$ is due to creative accounting that is to the accountants' skills than rather to a real economic growth". However, Jameson (1988)" appreciates the fact that accounting process in its essence, requires the operation with different motivations, different ideas. From this diversity, arise manipulation, cheating and falsification at some less scrupulous accounting members".

Creative accounting also known as aggressive accounting and is the manipulation of financial numbers, usually within the parameter of the law and accounting standards, but very much against their spirit and certainly not providing the true and fair view of a company that accounts are supposed to. A typical aim of creative accounting will be to inflate profit figures (Karim, Fowzia and Rashid 2014). A typical creative accounting incident involves both human effort and a bias towards some objective. Most typically, the objective is increased profits, inflated asset values, understated liabilities, and overstated shareholder value. The motivation of management and accountants typically being bonuses, promotion, and salary rises, etc.

According to a research conducted in same subject, "creative accounting is a euphemism referring to accounting practices that may follow the letter of the rules of standard accounting practices, but certainly deviate from the spirit of those rules".

The terms "innovative" or "aggressive" are also sometimes used. Other synonyms include cooking the books.

It further states that the term as generally understood refers to systematic misrepresentation of the true income and assets of corporations or other organizations. "Creative accounting" is at the root of a number of accounting scandals, and many proposals for accounting reform - usually centering on an updated analysis 


\section{ELK ASIA PACIFIC JOURNAL OF FINANCE AND RISK MANAGEMENT}

ISSN 2349-2325 (Online); DOI: 10.16962/EAPJFRM/issn. 2349-2325/2015; Volume 6 Issue 4 (2015)

of capital and factors of production that would correctly reflect how value is added

\section{Research Question}

Research question that deals this empirical study is as follows:

Q.1 Is there any gap in the perception between the Auditors and the Accountants regarding the fact that creative accounting is a form of blessing or curse or both?

\section{Research Methodology}

This study combines both primary and secondary data. Secondary data was collected through referring to books, literatures, journals, industrial reviews, company's financial reports, newspaper articles etc. as mentioned in the literature review.

Primary data was collected from the auditors and accountants practicing in Bangladesh. Sampling method was probability in nature. This should be noted that there are 1263 members in the Institute of Chartered Accountants of Bangladesh (ICAB) as of July 2012 of which 344 are auditors and 919 are qualified accountants. (source: www.icab.org.bd)

Of the 344 Auditors, they represent 158 Chartered Accountants Firm in the country. 79 Chartered Accountants Firms were surveyed (50\%) for their response in the category of Auditors. A total 50 Auditors were surveyed from listed companies and 100 Accountants was surveyed from listed companies as respondents as to form an opinion at national level and have a meaningful contribution.

Data was collected from these practicing auditors and accountants in Bangladesh by completing the questionnaire through face to face survey. Descriptive analysis and $\mathrm{t}$ - test was conducted to meet the research objectives and later on Chi Square test was conducted on the whole data collected to form opinion.

Descriptive analysis is a discipline that describes the main characteristics of a collection of data. The aim of the discipline is to summarize a set of data and $\mathrm{T}$ test is a statistical examination of two population means.

The questionnaire was developed using 5 point likert scale and all the data collected were first sorted into accountant and auditor. After this primary checking all the respondents questionnaire was thoroughly checked to ensure all the parts were answered and ticked properly. Later each data finding was compared with the reference table and comments was made regarding the significant and non significant of each variables. 


\section{ELK ASIA PACIFIC JOURNAL OF FINANCE AND RISK MANAGEMENT}

ISSN 2349-2325 (Online); DOI: 10.16962/EAPJFRM/issn. 2349-2325/2015; Volume 6 Issue 4 (2015)

\section{Literature Review}

The review begins by looking empirical literature on creative accounting, beginning with Healy's (1985) highly cited article, until present. According to Smith (1992), "considers that the highest part of the economic growth of the $80 \mathrm{~s}$ is due to creative accounting that is to the accountants' skills than rather to a real economic growth. In the book, Accounting for Growth, he motivates the previous idea, exemplifying the cases of some British companies which use creative accounting practices (finding concrete proofs at 45 economic entities of Great Britain), taking the example of three companies which experienced the financial collapse shortly after they had presented their financial statements which clearly reflected: financial stability. Here as well Smith, considers that the economic growth that took place in the 80 's is mainly due to the fact of window dressing in the form of rosy financial statements". In here Smith emphasized that the development of economic growth was on paper and figure rather than achieving in real terms. That is the art and practice of creative accounting on its own merit.

According to Merchant and Rockness (1994) creative accounting "Is any action on the part of management which affects reported income and which provides no true economic advantage to the organization and may in fact, in the longterm, be detrimental". Here too, Merchant and Rockness highlights that it's" the management who portrays certain financial statements to look in a certain way as in term it may not provide any economic advantage in real terms".

Creative accounting has been defined by Shah, (1998)" as the process by which management take advantage of gaps or ambiguities in accounting standards to present a biased picture of financial performance". According to Shah, it is said to be the" deliberate steps taken by the management in order to take advantages of the gaps in the rules and regulation of the accounting standard to an extent that the financial presentation will provide the user of the information a rosy picture regarding the state of the affairs of the reporting entity as of a particular date". In his opinion Jameson (1988) “ appreciates the fact that accounting process in its essence, requires the operation with different motivations, different ideas. From this diversity, arise manipulation, cheating and falsification at some less scrupulous accounting members. It is he who states that these creative accounting practices do not break the law or the accounting standards; therefore, 


\section{ELK ASIA PACIFIC JOURNAL OF FINANCE AND RISK MANAGEMENT}

ISSN 2349-2325 (Online); DOI: 10.16962/EAPJFRM/issn. 2349-2325/2015; Volume 6 Issue 4 (2015)

they comply with the law but not its spirit".

Since there is no agreed definition, Healy and Wahlen's (1999) is widely accepted one. Their article on reviews earnings management relevant to standards setters which leads them to the definition; "Earnings management occurs when managers use judgment in financial reporting and in structuring transactions to alter financial reports to either mislead some stakeholders about the underlying economic performance of the company or to influence contractual outcomes that depend on reported accounting numbers." Here we see that Healy and Wahlen stresses the point that earning management as often synonym for creative accounting occurs when the Managers are using judgments for the financial reports to be prepared for the stakeholders. Here comes the question who are the stakeholders ? Stakeholders are any person / group who has a direct or indirect interest in the business and may be an employee, tax authority, law enforcing authorities , pressure groups, the banks, insurance companies and even the competitors.

"Financial reporting enables firms to communicate economic information about their firm's performance. This information can be used to compare firms, showing the differences in economic position and performance of each firm (Healy and Wahlen, 1999). In order to portray information, managers must follow defined standards, but within these, there is room for interpretation and application of judgment over the financial reporting. Judgment in financial reporting leads to opportunities for creative accounting. Although there is no agreed definition, Healy and Wahlen's (1999, p.368) is widely accepted. Their article reviews earnings management relevant to standards setters which leads them to the definition; "Earnings management occurs when managers use judgment in financial reporting and in structuring transactions to alter financial reports to either mislead some stakeholders about the underlying economic performance of the company or to influence contractual outcomes that depend on reported accounting numbers."

Almost in the same manner, Trotman (1993) defines creative accounting, appreciating that it is a communication technique having in view the amelioration of the information provided to the investors. Thus, the economic entity is presenting to the investors or to the prospective investors financial statements passed through the filter of some techniques capable of generating a more favourable image on the market but also 


\section{ELK ASIA PACIFIC JOURNAL OF FINANCE AND RISK MANAGEMENT}

ISSN 2349-2325 (Online); DOI: 10.16962/EAPJFRM/issn. 2349-2325/2015; Volume 6 Issue 4 (2015)

the illusion of some more attractive results that the normal. (Balaciu, Bogdan and Vladu 2009)

In the literature, creative accounting can still be found under the name of income smoothing, earnings smoothing, cosmetic accounting or accounting cosmetics, financial crafts or accounting crafts.

"Creative accounting puts into practice in recent years not only in Bangladesh but also in a lot of developed countries. However, it is marked that the level of window-dressing of company financial statements in some developing countries has significantly desecrated all known ethical standards. ( Karim Fowzia \& Rashid 2011) Here Karim Fowzia and Rashid is emphasizing that the practice of creative accounting is now universal and there is now no limitation as to its application. Even the developing countries are practicing it regularly as the accounting legislative or watch dogs of the accounting rules and policies at times are very weak. Bangladesh being no exception where there has been cases of financial frauds in companies like Hall Mark ltd. and Destiny Groups".

(Sen and Inanga, 2001) summarize the speech of Jim Kennan, presented before the Australian Society of Accountants, which identified some significant effects of creative accounting. First, there are companies listed on the stock exchange, which show inflated profit and better financial position in their creative accounting statements to attract investors; this creation of accounts just misguides and creates confusion.

Yet another purpose of adapting creative accounting technique may be the managers are interested in paying less taxes and dividends the shareholders in gain with higher dividends, the employees to obtain better salary and higher profit share, the authorities to collect more taxes ( Junaid and Asif , 2014).

\section{Findings \& Analysis:}

Let us consider the formulation of hypothesis from the mainstream at first.

1. $\mathrm{H}_{\mathrm{A}}$ : To stay at par with forecast and actual.

2. $\mathrm{H}_{\mathrm{A}}$ : To stay at par with the industry best performer.

3. $\mathrm{H}_{\mathrm{A}}$ : To attract more stakeholder in to the business.

4. $\mathrm{H}_{\mathrm{A}}$ : To maintain the stability of share price in the stock exchange. 
(Refer Table 1 Here)

(Refer Table 2 Here)

1. $\mathrm{H}_{0}$ : There is no difference between the opinions of two groups in practicing creative accounting as to stay at par with the forecast and the actual.

And $\mathrm{H}_{\mathrm{A}}$ : There is a difference between the opinions of two groups in practicing creative accounting as not to stay at par with the forecast and actual.

(Refer Table 3 Here)

Chi-square

value $=\sum \frac{(O-E)^{2}}{E}=14.54$

The degrees of freedom are $(\mathrm{R}-1)(\mathrm{C}-1)=$ $(2-1)(4-1)=3$. At $5 \%$ level of significance, the critical value from Gdistribution is 7.815 .

Since $14.54>7.815$ that means chi-square value falls into the critical region, the decision is to reject null hypothesis. So at $5 \%$ level of significance, it can be said that there is enough evidence to support the claim that there is gap between the opinions of two groups about its application in

Obviously there will be a perception gap in the view point of auditors and accountants here.
And hence there are difference of opinions.

If we look into the graph below we can comment on the performance.

(Refer Figure 1 Here)

Here we can see that $64 \%$ of the respondent who are auditors responses that they are neutral on the fact that creative accounting is practiced in Bangladesh by the entities to stay at par with the expectations. While $78.6 \%(63.1+15.5)$ of the accountants agree and strongly agrees to the fact that creative accounting is practiced in the economy by the entities to stay at par with the expectations.

2. $\mathrm{H}_{0}$ : There is no difference between the opinions of two groups in saying that to stay at par with the industry's best performer.

And $\mathrm{H}_{\mathrm{A}}$ : There is a difference between the opinions of two groups in saying that not to stay in par with the industry's best perfomer.

(Refer Table 4 Here)

Chi-square value $=\sum \frac{(O-E)^{2}}{E}=$ 14.54

The degrees of freedom are $(\mathrm{R}-1)(\mathrm{C}-1)=$ $(2-1)(4-1)=3$. At $5 \%$ level of significance, the critical value from G- 


\section{ELK ASIA PACIFIC JOURNAL OF FINANCE AND RISK MANAGEMENT}

ISSN 2349-2325 (Online); DOI: 10.16962/EAPJFRM/issn. 2349-2325/2015; Volume 6 Issue 4 (2015)

distribution is 7.815 . Since $14.54>7.815$ that means chi-square value falls into the critical region, the decision is to reject null hypothesis. So at $5 \%$ level of significance, it can be said that there is enough evidence to support the claim that there is gap between the opinions of two groups about its application in Obviously there will be a perception gap in the view point of auditors and accountants here.

And hence there are difference of opinions.

(Refer Table 5)

(Refer Table 6)

Chi-square value $=\sum \frac{(O-E)^{2}}{E}$

The degrees of freedom are $(\mathrm{R}-1)(\mathrm{C}-1)=$ $(2-1)(4-1)=3$. At $5 \%$ level of significance, the critical value from Gdistribution is analyzed and reflected in the graph..

Since that means chi-square value falls into the critical region, the decision is to reject null hypothesis. So at 5\% level of significance, it can be said that there is enough evidence to support the claim that there is gap between the opinions of two groups about its application in
Obviously there will be a perception gap in the view point of auditors and accountants here.

And hence there are difference of opinions.

3. $\mathrm{H}_{0}$ : There is no difference between the opinions of two groups in attracting more stakeholders into the business.

And $\mathrm{H}_{\mathrm{A}}$ : There is a difference between the opinions of two groups in not attracting more stakeholders into the business.

(Refer Table 7 Here)

Let us analyze the above fact more closely by the following diagram.

\section{(Refer Figure 2 Here)}

Here we can see that $77.5 \%$ of the accountant responded that to attract new and more stakeholders the practice of creative is carried out. On the other hand the respondent group of auditor suggests that only $24 \%$ either agrees and strongly agrees with the fact that to attract new investor in to the business. 


\section{ELK ASIA PACIFIC JOURNAL OF FINANCE AND RISK MANAGEMENT}

ISSN 2349-2325 (Online); DOI: 10.16962/EAPJFRM/issn. 2349-2325/2015; Volume 6 Issue 4 (2015)

4. $\mathrm{H}_{0}$ : There is no difference between the opinions of two groups in saying that to maintain the stability of the share price in the stock market.

And $\mathrm{H}_{\mathrm{A}}$ : There is a difference between the opinions of two groups in saying that to maintain the stability of share price in the stock market.

(Refer Table 8 Here)

Chi-square value $=\sum \frac{(O-E)^{2}}{E}$

The degrees of freedom are $(\mathrm{R}-1)(\mathrm{C}-1)=$ $(2-1)(4-1)=3$. At $5 \%$ level of significance, the critical value from Gdistribution is calculated and reflection of summary is shown in the graph.

Since that means chi-square value falls into the critical region, the decision is to reject null hypothesis. So at 5\% level of significance, it can be said that there is enough evidence to support the claim that there is gap between the opinions of two groups about its application in

Obviously there will be a perception gap in the view point of auditors and accountants here.

And hence there are difference of opinions.

(Refer Table 9 Here)
(Refer Table 10 Here)

Let us examine the graph below:

(Refer Figure 3 Here)

The following table will make it clear.

Here we can see $79.6 \%$ of the accountants responded that to maintain the stability in the share market regarding the value of the share such practice is used.

Whereas $56 \%$ of the auditors had no comment and responded as neutral to this particular question.

(Refer Table 11 Here)

(Refer Table 12 Here)

(Refer Table 13 Here)

(Refer Table 14 Here)

Here also we that $81.5 \%$ of the accountants either agrees or strongly agrees as compared to only $48 \%$ of the auditors. The graph below will be more speaking about the situation.

(Refer Figure 4 Here)

(Refer Table 12 Here)

(Refer Table 15 Here)

(Refer Table 16 Here)

\section{Conclusion}

To analyze this research question we formulated 4 hypotheses based on part A of the questionnaire and following is the main conclusion of it. 


\section{ELK ASIA PACIFIC JOURNAL OF FINANCE AND RISK MANAGEMENT}

ISSN 2349-2325 (Online); DOI: 10.16962/EAPJFRM/issn. 2349-2325/2015; Volume 6 Issue 4 (2015)

Listed companies auditors and accountants responded as follows:

To our first hypothesis for part A of the questionnaire 1 question, here we can see that $64 \%$ of the respondent who are auditors responses that they are neutral on the fact that creative accounting is practiced in Bangladesh by the entities to stay at par with the expectations. While $78.6 \%(63.1+15.5)$ of the accountants agree and strongly agrees to the fact that creative accounting is practiced in the economy by the entities to stay at par with the expectations.

Listed companies auditors and accountants responded as follows for question 2 :

Here we can see that $44 \%$ of the respondent who are auditors responses that they are neutral on the fact that creative accounting is practiced in Bangladesh by the entities to stay at par with the industry's best performer expectations. While $68.2 \% \quad(43.1+25.1)$ of the accountants agree and strongly agrees to the fact that creative accounting is practiced in the economy by the entities to stay at par with the expectations.
The responses to our question 3 of part $\mathrm{A}$ questions were as follows:

Listed companies auditors and accountants: Here we can see that $77.5 \%$ of the accountant responded that to attract new and more stakeholders the practice of creative is carried out. On the other hand the respondent group of auditor suggests that only $24 \%$ both agrees and strongly agrees with the fact that to attract new investor in to the business.

The response to our last question that is question number 4 of part $\mathrm{A}$ we received the following responses:

Listed company's auditors and accountants:

Here we can see $79.6 \%$ of the accountants responded that to maintain the stability in the share market regarding the value of the share such practice is used. Whereas $56 \%$ of the auditors had no comment and responded as neutral to this particular question.

\section{References:}

1. Balaciu, Bogdan and Vladu, (2009), “A Brief Review of Creative Accounting Literature and its Consequences in Practice." 


\section{ELK ASIA PACIFIC JOURNAL OF FINANCE AND RISK MANAGEMENT}

ISSN 2349-2325 (Online); DOI: 10.16962/EAPJFRM/issn. 2349-2325/2015; Volume 6 Issue 4 (2015)

Annales Universitatis Apulensis

Series Oeconomica, 11(1), 2009

2. Copeland, R.M.: (1968) 'Income smoothing', Journal of Accounting Research, VVI, Supplement, pp.101-116.

3. Griffiths, I., (1986). Creative accounting, Sidgwick\&Jackson, pp. 1

4. Griffiths, Ian (1992), Creative Accounting: How to make your profits what you want them to be (London: Routledge, First published in 1986).

5. Healy, P.M. and Wahlen, J.M.: (1999) 'A review of the creative accounting literature and its implications for standard setting', Accounting Horizons, Vol. 13, No. 4, pp. 365-83.

6. IASB: (2003) 'International Accounting Standards'. London: IASB.

7. Jameson, M. (1988). A practical guide to creative accounting, Kogan Page

8. Karim, Fowzia \& Rashid (2011): Cosmetic Accounting Practices in Developing Countries :

Bangladesh Perspectives, World Journal of Social Sciences ,Australia, Vol.1, No.3, July . 2011 Pp. 1-15

9. Karim and Junaid (2014): " Creative Accounting - a form of manipulation “ Port City International University Journal Vol. 1, Issue. 1
10. Karim, Fowzia \& Rashid (2014) , “ Prception gap analysis between external auditors and accountants in application of Creative Accounting Techniques in Bangladesh" , International Journal of Managerial Finance \& Accounting, UK Merchant, K.A. and Rockness, J.: (1994) 'The ethics of managing earnings: empirical investigation', Journal of Accounting and Public Policy, 13, pp.7994.

Menciu and Cotlet " creative accounting important part of the enterprise result. Result Annals of Eftionie Murgu University-Resita, Fesdu.

11. Schipper, K.: (1989) 'Commentary on creative accounting, Accounting Horizons, December, pp. 91-102.

12. Shah A K (1988) " Exploring the influences and constrains of Creative Accounting in the UK, European Accounting Review, Vol. 7, 1, Pp. 83104.

13. Smith, T., (1992). Accounting for growth, London: Century Business

14. Watts, R.L., and Zimmerman, J.L.,(1978). Positive Accounting Theory. Prentice-Hall, Englewood cliffs.

15. Watts, R.L., Zimmerman J.L., (1986). Positive accounting theory, Prentice Hall international . Inc.

16. Watts, R.L., Zimmerman J.L., (1990). Positive accounting theory: A ten year 


\section{ELK ASIA PACIFIC JOURNAL OF FINANCE AND RISK MANAGEMENT}

ISSN 2349-2325 (Online); DOI: 10.16962/EAPJFRM/issn. 2349-2325/2015; Volume 6 Issue 4 (2015)

perspective, Accounting Review, 65, pp.131-156

\section{List of Figures:}


ELK ASIA PACIFIC JOURNAL OF FINANCE AND RISK MANAGEMENT

ISSN 2349-2325 (Online); DOI: 10.16962/EAPJFRM/issn. 2349-2325/2015; Volume 6 Issue 4 (2015)

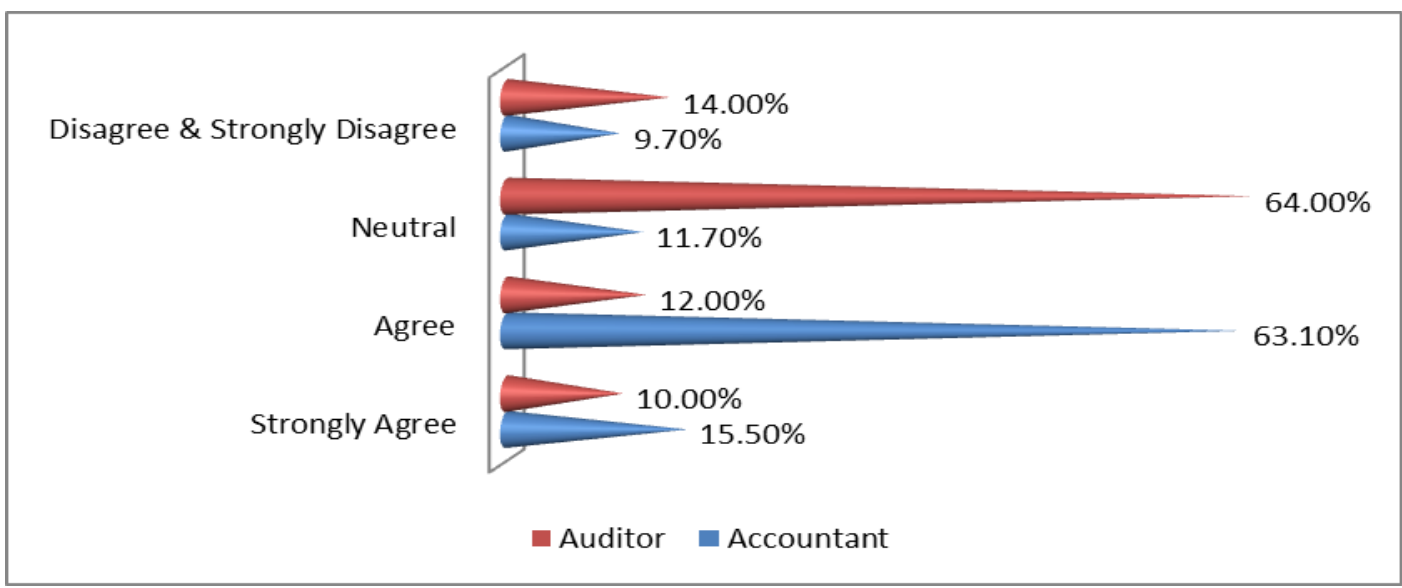

Figure 1: Graphical representation of the analysis of the questionnaire

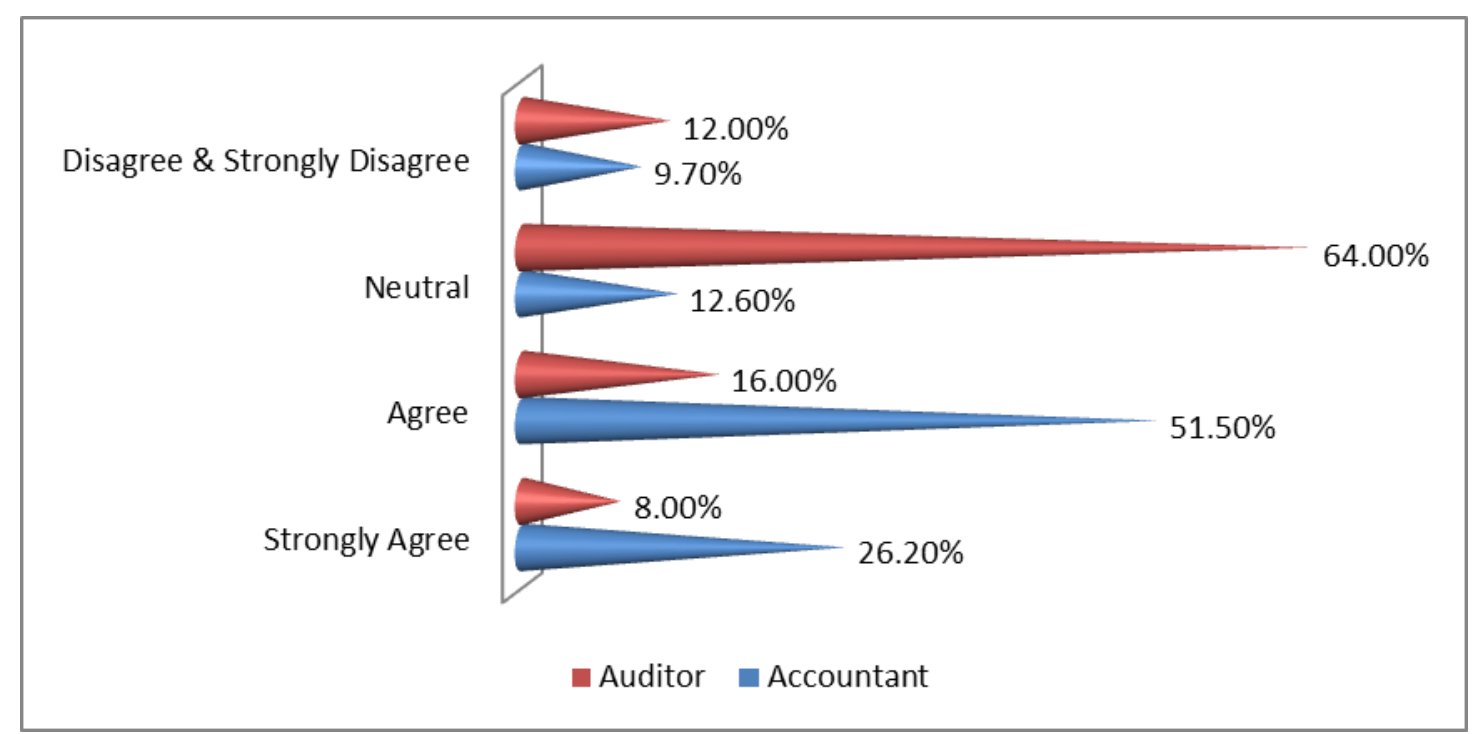

Figure 2: Graphical representation of the analysis of the questionnaire 
ELK ASIA PACIFIC JOURNAL OF FINANCE AND RISK MANAGEMENT

ISSN 2349-2325 (Online); DOI: 10.16962/EAPJFRM/issn. 2349-2325/2015; Volume 6 Issue 4 (2015)

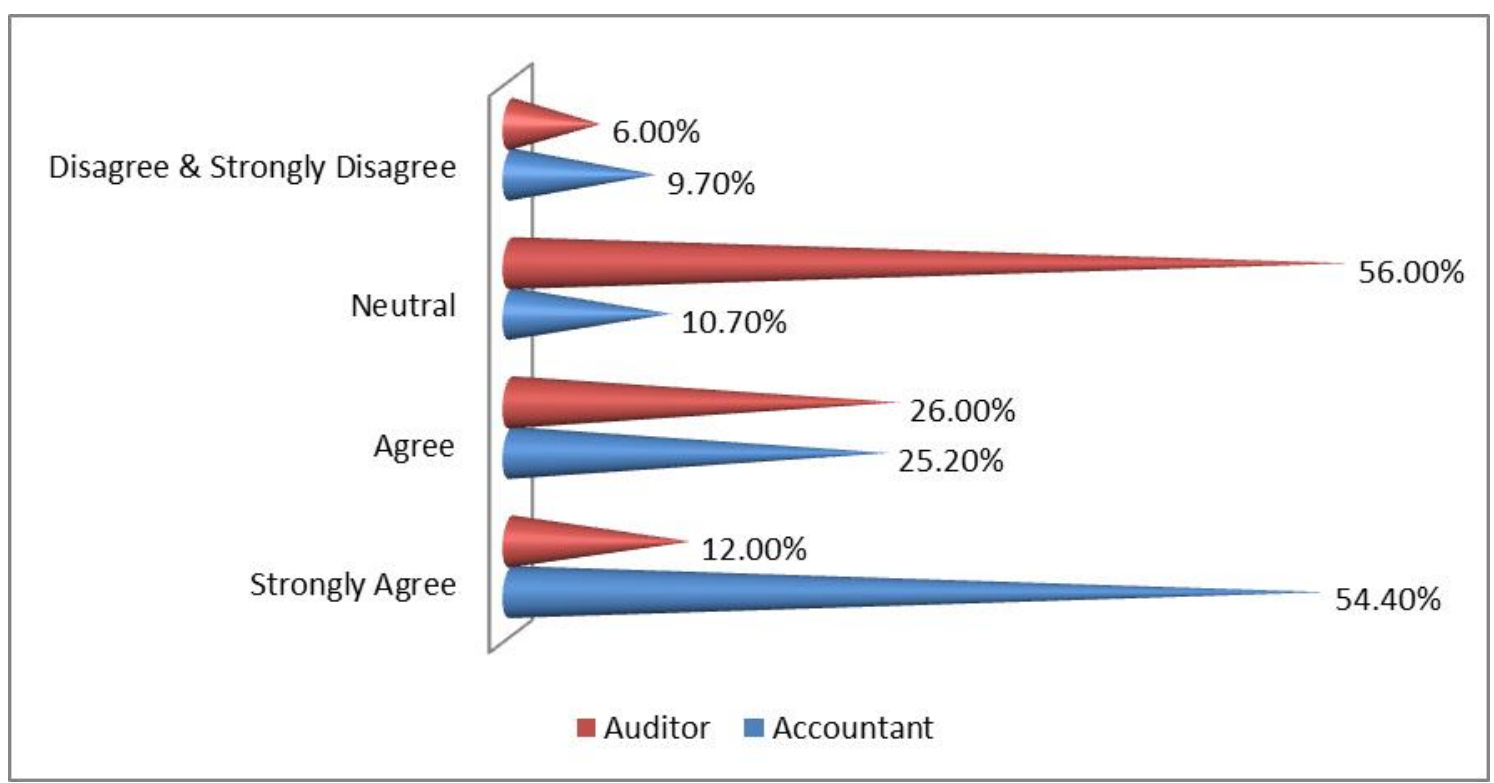

Figure 3: Graphical representation of the analysis of the questionnaire

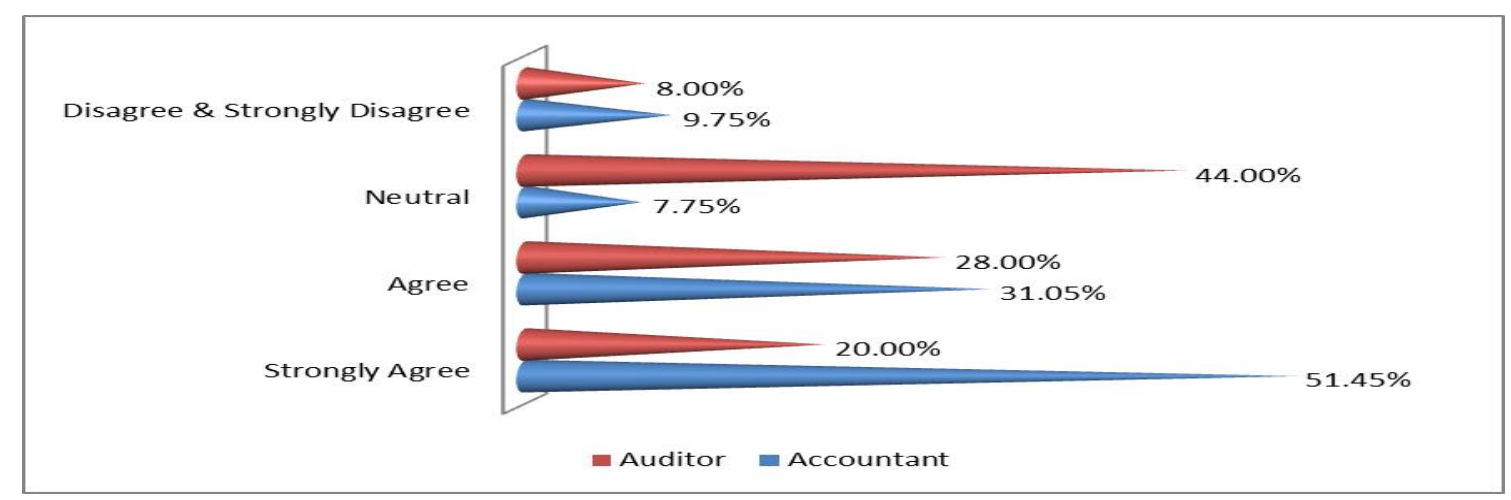

Figure 4: Graphical representation of the analysis of the questionnaire 


\section{List of Tables:}

Table - 1: Global name for Creative accounting

\begin{tabular}{|l|l|}
\hline Country & Equivalent Term to Creative Accounting \\
\hline Switzerland & Bilanzmanipulation, Bilanzkosmetik \\
\hline Germany & Tricksereien, Bilanzartistik \\
\hline Holland & Winsteagalisatie, Creatief boekhouden \\
\hline France & Bricolage(DIY), Fabricated Accounts \\
\hline USA & Cooking the books, earnings management \\
\hline Italy & Politiche di bilancio \\
\hline Japan & Furyo Kessan, Kara-uri, Funshoku \\
\hline Australia & Fudging, Feral Accounting \\
\hline Great Britain & Window Dressing, Bubbles \\
\hline
\end{tabular}

Source: Audit Committee Newsletter, KPMG, June 2003

Table 2: Case Processing Summary

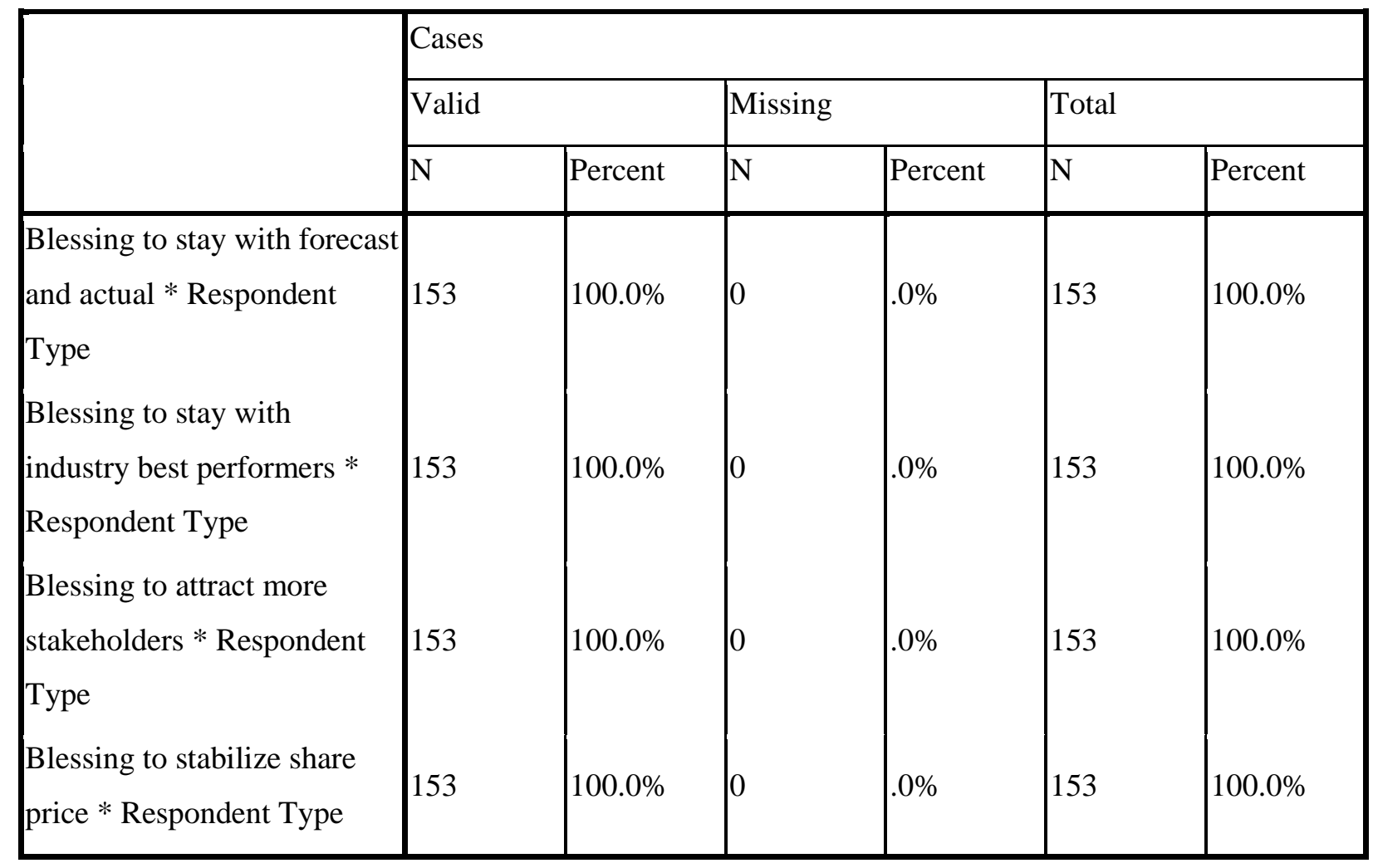

Table 3 : Blessing to stay with forecast and actual * Respondent Type Cross tabulation 
ELK ASIA PACIFIC JOURNAL OF FINANCE AND RISK MANAGEMENT

ISSN 2349-2325 (Online); DOI: 10.16962/EAPJFRM/issn. 2349-2325/2015; Volume 6 Issue 4 (2015)

\begin{tabular}{|c|c|c|c|c|c|}
\hline & & & \multicolumn{2}{|c|}{ Respondent Type } & \multirow[b]{2}{*}{ Total } \\
\hline & & & Accountant & Auditor & \\
\hline \multirow{6}{*}{$\begin{array}{l}\text { Blessing to stay with } \\
\text { forecast and actual }\end{array}$} & strongly agree & Count & 16 & 5 & 21 \\
\hline & & $\begin{array}{l}\% \text { within Respondent } \\
\text { Type }\end{array}$ & $15.5 \%$ & $10.0 \%$ & $13.7 \%$ \\
\hline & Agree & $\begin{array}{l}\text { Count } \\
\text { \% within Respondent } \\
\text { Type }\end{array}$ & $\begin{array}{l}65 \\
63.1 \%\end{array}$ & $\begin{array}{l}6 \\
12.0 \%\end{array}$ & $\begin{array}{l}71 \\
46.4 \%\end{array}$ \\
\hline & Neutral & $\begin{array}{l}\text { Count } \\
\text { \% within Respondent } \\
\text { Type }\end{array}$ & $\begin{array}{l}12 \\
11.7 \%\end{array}$ & $\begin{array}{l}32 \\
64.0 \%\end{array}$ & $\begin{array}{l}44 \\
28.8 \%\end{array}$ \\
\hline & Disagree & $\begin{array}{l}\text { Count } \\
\text { \% within Respondent } \\
\text { Type }\end{array}$ & $\mid \begin{array}{l}6 \\
5.8 \%\end{array}$ & $\begin{array}{l}6 \\
12.0 \%\end{array}$ & $\begin{array}{l}12 \\
7.8 \%\end{array}$ \\
\hline & strongly disagree & $\begin{array}{l}\text { Count } \\
\text { \% within Respondent } \\
\text { Type }\end{array}$ & $3.9 \%$ & $\begin{array}{l}1 \\
2.0 \%\end{array}$ & $3.3 \%$ \\
\hline Total & & $\begin{array}{l}\text { Count } \\
\text { \% within Respondent } \\
\text { Type }\end{array}$ & $\begin{array}{l}103 \\
100.0 \%\end{array}$ & $\begin{array}{l}50 \\
100.0 \%\end{array}$ & $\begin{array}{l}153 \\
100.0 \%\end{array}$ \\
\hline
\end{tabular}

Table 4: Observed frequencies (expected frequency) of respondent's opinions about company's staying at par with the forecast and the actual.

\begin{tabular}{|l|l|l|l|l|l|}
\hline & Strongly Agree & Agree & Neutral & $\begin{array}{l}\text { Disagree \& Strongly } \\
\text { Disagree }\end{array}$ & Total \\
\hline Accountant & $16(14.14)$ & $65(47.80)$ & $12(29.62)$ & $10(11.44)$ & 103 \\
\hline Auditor & $5(6.86)$ & $6(23.20)$ & $32(14.40)$ & $7(5.56)$ & 50 \\
\hline Total & 21 & 71 & 44 & 17 & 153 \\
\hline
\end{tabular}

Table 5: Observed frequencies (expected frequency) of respondent's opinions about company's staying at par with the forecast and the actual. 
ELK ASIA PACIFIC JOURNAL OF FINANCE AND RISK MANAGEMENT

ISSN 2349-2325 (Online); DOI: 10.16962/EAPJFRM/issn. 2349-2325/2015; Volume 6 Issue 4 (2015)

\begin{tabular}{|l|l|l|l|l|}
\hline \multicolumn{2}{|l|}{ Contingency Table } & & & Disagree \& Strongly \\
& Strongly Agree & Agree & Neutral & Disagree \\
\hline Accountant & 14.1372549 & 47.79738562 & 29.62091503 & 11.44444 \\
\hline Auditor & 6.862745098 & 23.20261438 & 14.37908497 & 5.555556 \\
\hline
\end{tabular}

Table 6: Chi-Square Value

\begin{tabular}{|l|l|l|l|l|}
\hline Observed & Expected & $\mathrm{O}-\mathrm{E}=\mathrm{V}$ & $\mathrm{V} * \mathrm{~V}=\mathrm{X}$ & $\mathrm{X} / \mathrm{E}$ \\
\hline 16 & 14.1372549 & 1.862745098 & 3.469819 & 0.245437981 \\
\hline 65 & 47.79738562 & 17.20261438 & 295.9299 & 6.19134159 \\
\hline 12 & 29.62091503 & -17.62091503 & 310.4966 & 10.48234486 \\
\hline 10 & 11.44444444 & -1.444444444 & 2.08642 & 0.182308522 \\
\hline 5 & 6.862745098 & -1.862745098 & 3.469819 & 0.505602241 \\
\hline 6 & 23.20261438 & -17.20261438 & 295.9299 & 12.75416367 \\
\hline 32 & 14.37908497 & 17.62091503 & 310.4966 & 21.59363042 \\
\hline 7 & 5.555555556 & 1.444444444 & 2.08642 & 0.375555556 \\
\hline & & & Total & 52.33038485 \\
\hline
\end{tabular}

Table 7: Blessing to stay with industry best performers * Respondent Type Cross tabulation

\begin{tabular}{|c|c|c|c|c|c|}
\hline & & & \multicolumn{2}{|c|}{ Respondent Type } & \multirow[b]{2}{*}{ Total } \\
\hline & & & $\begin{array}{l}\text { Accounta } \\
\text { nt }\end{array}$ & Auditor & \\
\hline \multirow[t]{3}{*}{$\begin{array}{l}\text { Blessing to stay with } \\
\text { industry best } \\
\text { performers }\end{array}$} & strongly agree & $\begin{array}{l}\text { Count } \\
\% \text { within Respondent } \\
\text { Type }\end{array}$ & 27 & 4 & $20.3 \%$ \\
\hline & Agree & $\begin{array}{l}\text { Count } \\
\% \text { within Respondent } \\
\text { Type }\end{array}$ & 53 & $\begin{array}{l}8 \\
16.0 \%\end{array}$ & $\begin{array}{l}61 \\
39.9 \%\end{array}$ \\
\hline & Neutral & Count & 13 & 32 & 45 \\
\hline
\end{tabular}


ELK ASIA PACIFIC JOURNAL OF FINANCE AND RISK MANAGEMENT

ISSN 2349-2325 (Online); DOI: 10.16962/EAPJFRM/issn. 2349-2325/2015; Volume 6 Issue 4 (2015)

\begin{tabular}{|c|c|c|c|c|c|}
\hline & & $\begin{array}{l}\% \text { within Respondent } \\
\text { Type }\end{array}$ & $12.6 \%$ & $64.0 \%$ & $29.4 \%$ \\
\hline & Disagree & $\begin{array}{l}\text { Count } \\
\% \text { within Respondent } \\
\text { Type }\end{array}$ & $5.8 \%$ & $\begin{array}{l}6 \\
12.0 \%\end{array}$ & $\begin{array}{l}12 \\
7.8 \%\end{array}$ \\
\hline & $\begin{array}{l}\text { strongly } \\
\text { disagree }\end{array}$ & $\begin{array}{l}\text { Count } \\
\% \text { within Respondent } \\
\text { Type }\end{array}$ & 4 & 0 & 4 \\
\hline Total & & $\begin{array}{l}\text { Count } \\
\% \text { within Respondent } \\
\text { Type }\end{array}$ & $\begin{array}{l}103 \\
100.0 \%\end{array}$ & $100.0 \%$ & $\begin{array}{l}153 \\
100.0 \%\end{array}$ \\
\hline
\end{tabular}

Table 8: Observed frequencies (expected frequency) of respondent's opinions about company's staying at par with the forecast and the actual.

\begin{tabular}{|l|l|l|l|l|l|}
\hline & Strongly Agree & Agree & Neutral & $\begin{array}{l}\text { Disagree \& } \\
\text { Strongly Disagree }\end{array}$ & Total \\
\hline Accountant & $27(20.87)$ & $53(41.07)$ & $13(30.29)$ & $10(10.77)$ & 103 \\
\hline Auditor & $4(10.13)$ & $8(19.94)$ & $32(14.71)$ & $6(5.23)$ & 50 \\
\hline Total & 31 & 61 & 45 & 16 & 153 \\
\hline
\end{tabular}

Table 9: Observed frequencies (expected frequency) of respondent's opinions about company's staying at par with the forecast and the actual.

\begin{tabular}{|l|l|l|l|l|}
\hline \multicolumn{2}{|l|}{ Contingency Table } \\
& Strongly Agree & Agree & Neutral & $\begin{array}{l}\text { Disagree \& Strongly } \\
\text { Disagree }\end{array}$ \\
\hline Accountant & 20.86928105 & 41.06535948 & 30.29411765 & 10.77124 \\
\hline Auditor & 10.13071895 & 19.93464052 & 14.70588235 & 5.228758 \\
\hline
\end{tabular}

Table - 10 Chi-Square Value

\begin{tabular}{|l|l|l|l|l|}
\hline Observed & Expected & $\mathrm{O}-\mathrm{E}=\mathrm{V}$ & $\mathrm{V} * \mathrm{~V}=\mathrm{X}$ & $\mathrm{X} / \mathrm{E}$ \\
\hline
\end{tabular}


ELK ASIA PACIFIC JOURNAL OF FINANCE AND RISK MANAGEMENT

ISSN 2349-2325 (Online); DOI: 10.16962/EAPJFRM/issn. 2349-2325/2015; Volume 6 Issue 4 (2015)

\begin{tabular}{|l|l|l|l|l|}
27 & 20.86928105 & 6.130718954 & 37.58571 & 1.801006696 \\
\hline 53 & 41.06535948 & 11.93464052 & 142.4356 & 3.468510838 \\
\hline 13 & 30.29411765 & -17.29411765 & 299.0865 & 9.872758424 \\
\hline 10 & 10.77124183 & -0.77124183 & 0.594814 & 0.055222413 \\
\hline 4 & 10.13071895 & -6.130718954 & 37.58571 & 3.710073793 \\
\hline 8 & 19.93464052 & -11.93464052 & 142.4356 & 7.145132326 \\
\hline 32 & 14.70588235 & 17.29411765 & 299.0865 & 20.33788235 \\
\hline 6 & 5.22875817 & 0.77124183 & 0.594814 & 0.11375817 \\
\hline & & & Total & 46.50434501 \\
\hline
\end{tabular}

Table - 11 Blessing to attract more stakeholders * Respondent Type Cross tabulation

\begin{tabular}{|c|c|c|c|c|c|}
\hline & & & \multicolumn{2}{|c|}{ Respondent Type } & \multirow[b]{2}{*}{ Total } \\
\hline & & & Accountant & Auditor & \\
\hline \multirow[t]{5}{*}{$\begin{array}{l}\text { Blessing to attract more } \\
\text { stakeholders }\end{array}$} & strongly agree & $\begin{array}{l}\text { Count } \\
\% \text { within Respondent } \\
\text { Type }\end{array}$ & $\begin{array}{l}56 \\
54.4 \%\end{array}$ & $\begin{array}{l}6 \\
12.0 \%\end{array}$ & $\begin{array}{l}62 \\
40.5 \%\end{array}$ \\
\hline & Agree & $\begin{array}{l}\text { Count } \\
\% \text { within Respondent } \\
\text { Type }\end{array}$ & $\begin{array}{l}26 \\
25.2 \%\end{array}$ & $\begin{array}{l}13 \\
26.0 \%\end{array}$ & $25.5 \%$ \\
\hline & Neutral & $\begin{array}{l}\text { Count } \\
\% \text { within Respondent } \\
\text { Type }\end{array}$ & $\begin{array}{l}11 \\
10.7 \%\end{array}$ & $\begin{array}{l}28 \\
56.0 \%\end{array}$ & $25.5 \%$ \\
\hline & Disagree & $\begin{array}{l}\text { Count } \\
\% \text { within Respondent } \\
\text { Type }\end{array}$ & $\begin{array}{l}6 \\
5.8 \%\end{array}$ & $6.0 \%$ & $5.9 \%$ \\
\hline & strongly disagree & $\begin{array}{l}\text { Count } \\
\% \text { within Respondent } \\
\text { Type }\end{array}$ & $\begin{array}{l}4 \\
3.9 \%\end{array}$ & $\begin{array}{l}0 \\
.0 \%\end{array}$ & $\mid \begin{array}{l}4 \\
2.6 \%\end{array}$ \\
\hline Total & & Count & 103 & 50 & 153 \\
\hline
\end{tabular}


Table -11 Blessing to attract more stakeholders * Respondent Type Cross tabulation

\begin{tabular}{|c|c|c|c|c|c|}
\hline & & & \multicolumn{2}{|c|}{ Respondent Type } & \multirow[b]{2}{*}{ Total } \\
\hline & & & Accountant & Auditor & \\
\hline \multirow[t]{5}{*}{$\begin{array}{l}\text { Blessing to attract more } \\
\text { stakeholders }\end{array}$} & strongly agree & $\begin{array}{l}\text { Count } \\
\% \text { within Respondent } \\
\text { Type }\end{array}$ & $\begin{array}{l}56 \\
54.4 \%\end{array}$ & $\begin{array}{l}6 \\
12.0 \%\end{array}$ & $\begin{array}{l}62 \\
40.5 \%\end{array}$ \\
\hline & Agree & $\begin{array}{l}\text { Count } \\
\% \text { within Respondent } \\
\text { Type }\end{array}$ & $\begin{array}{l}26 \\
25.2 \%\end{array}$ & $\begin{array}{l}13 \\
26.0 \%\end{array}$ & $\mid \begin{array}{l}39 \\
25.5 \%\end{array}$ \\
\hline & Neutral & $\begin{array}{l}\text { Count } \\
\% \text { within Respondent } \\
\text { Type }\end{array}$ & $\begin{array}{l}11 \\
10.7 \%\end{array}$ & $\begin{array}{l}28 \\
56.0 \%\end{array}$ & $25.5 \%$ \\
\hline & Disagree & $\begin{array}{l}\text { Count } \\
\% \text { within Respondent } \\
\text { Type }\end{array}$ & $\begin{array}{l}6 \\
5.8 \%\end{array}$ & $6.0 \%$ & $5.9 \%$ \\
\hline & strongly disagree & $\begin{array}{l}\text { Count } \\
\% \text { within Respondent } \\
\text { Type }\end{array}$ & $\begin{array}{l}4 \\
3.9 \%\end{array}$ & $.0 \%$ & $\mid \begin{array}{l}4 \\
2.6 \%\end{array}$ \\
\hline Total & & $\begin{array}{l}\text { Count } \\
\% \text { within Respondent } \\
\text { Type }\end{array}$ & $\begin{array}{l}103 \\
100.0 \%\end{array}$ & $\mid \begin{array}{l}50 \\
100.0 \%\end{array}$ & $\begin{array}{l}153 \\
100.0 \%\end{array}$ \\
\hline
\end{tabular}

\begin{tabular}{|l|l|l|l|l|l|}
\hline & Strongly Agree & Agree & Neutral & $\begin{array}{l}\text { Disagree \& Strongly } \\
\text { Disagree }\end{array}$ & Total \\
\hline Accountant & $56(41.74)$ & $26(26.26)$ & $11(26.26)$ & $10(8.75)$ & 103 \\
\hline Auditor & $6(20.26)$ & $13(12.75)$ & $28(12.75)$ & $3(4.25)$ & 50 \\
\hline Total & 62 & 39 & 39 & 13 & 153 \\
\hline
\end{tabular}


Table 12: Observed frequencies (expected frequency) of respondent's opinions in

\begin{tabular}{|l|l|l|l|l|}
\hline \multicolumn{2}{|l|}{ Contingency Table } & & Disagree \& Strongly \\
& Strongly Agree & Agree & Neutral & Disagree \\
\hline & 41.73856209 & 26.25490196 & 26.25490196 & 8.751634 \\
\hline Accountant & 20.26143791 & 12.74509804 & 12.74509804 & 4.248366 \\
\hline Auditor &
\end{tabular}

Table 13 - Chi-Square Value

\begin{tabular}{|l|l|l|l|l|}
\hline Observed & Expected & $\mathrm{O}-\mathrm{E}=\mathrm{V}$ & $\mathrm{V} * \mathrm{~V}=\mathrm{X}$ & $\mathrm{X} / \mathrm{E}$ \\
\hline 56 & 41.73856209 & 14.26143791 & 203.3886 & 4.872918496 \\
\hline 26 & 26.25490196 & -0.254901961 & 0.064975 & 0.002474776 \\
\hline 11 & 26.25490196 & -15.25490196 & 232.712 & 8.863565142 \\
\hline 10 & 8.751633987 & 1.248366013 & 1.558418 & 0.178071627 \\
\hline 6 & 20.26143791 & -14.26143791 & 203.3886 & 10.0382121 \\
\hline 13 & 12.74509804 & 0.254901961 & 0.064975 & 0.005098039 \\
\hline 28 & 12.74509804 & 15.25490196 & 232.712 & 18.25894419 \\
\hline 3 & 4.248366013 & -1.248366013 & 1.558418 & 0.366827552 \\
\hline & & & Total & 42.58611193 \\
\hline
\end{tabular}


ELK ASIA PACIFIC JOURNAL OF FINANCE AND RISK MANAGEMENT

ISSN 2349-2325 (Online); DOI: 10.16962/EAPJFRM/issn. 2349-2325/2015; Volume 6 Issue 4 (2015)

Table 14 - Blessing to stabilize share price * Respondent Type Cross tabulation

\begin{tabular}{|c|c|c|c|c|c|}
\hline & & & \multicolumn{2}{|c|}{ Respondent Type } & \multirow[b]{2}{*}{ Total } \\
\hline & & & Accountant & Auditor & \\
\hline \multirow{6}{*}{$\begin{array}{l}\text { Blessing to stabilize } \\
\text { share price }\end{array}$} & strongly agree & Count & 53 & 10 & 63 \\
\hline & & $\begin{array}{l}\% \text { within Respondent } \\
\text { Type }\end{array}$ & $51.5 \%$ & $20.0 \%$ & $41.2 \%$ \\
\hline & Agree & $\begin{array}{l}\text { Count } \\
\% \text { within Respondent } \\
\text { Type }\end{array}$ & $\mid \begin{array}{l}32 \\
31.1 \%\end{array}$ & $28.0 \%$ & $\begin{array}{l}46 \\
30.1 \%\end{array}$ \\
\hline & Neutral & $\begin{array}{l}\text { Count } \\
\% \text { within Respondent } \\
\text { Type }\end{array}$ & $\mid \begin{array}{l}8 \\
7.8 \%\end{array}$ & $\begin{array}{l}22 \\
44.0 \%\end{array}$ & $\begin{array}{l}30 \\
19.6 \%\end{array}$ \\
\hline & Disagree & $\begin{array}{l}\text { Count } \\
\% \text { within Respondent } \\
\text { Type }\end{array}$ & $\mid \begin{array}{l}5 \\
4.9 \%\end{array}$ & $6.0 \%$ & 8 \\
\hline & strongly disagr & $\begin{array}{l}\text { Count } \\
\% \text { within Respondent } \\
\text { Type }\end{array}$ & $\mid \begin{array}{l}5 \\
4.9 \%\end{array}$ & $2.0 \%$ & $\begin{array}{l}6 \\
3.9 \%\end{array}$ \\
\hline Total & & $\begin{array}{l}\text { Count } \\
\% \text { within Respondent } \\
\text { Type }\end{array}$ & $\mid \begin{array}{l}103 \\
100.0 \%\end{array}$ & $100.0 \%$ & $\begin{array}{l}153 \\
100.0 \%\end{array}$ \\
\hline
\end{tabular}

Table 15 : Observed frequencies (expected frequency) of respondent's opinions in

\begin{tabular}{|l|l|l|l|l|l|}
\hline & Strongly Agree & Agree & Neutral & $\begin{array}{l}\text { Disagree \& } \\
\text { Strongly Disagree }\end{array}$ & Total \\
\hline Accountant & $53(42.42)$ & $32(30.98)$ & $8(20.20)$ & $10(9.43)$ & 103 \\
\hline Auditor & $10(20.59)$ & $14(15.03)$ & $22(9.80)$ & $4(4.58)$ & 50 \\
\hline Total & 63 & 46 & 30 & 14 & 153 \\
\hline
\end{tabular}


Table 16: Observed frequencies (expected frequency) of respondent's opinions in

\begin{tabular}{|l|l|l|l|l|}
\hline \multicolumn{5}{|l|}{ Contingency Table } \\
& Strongly Agree & Agree & Neutral & $\begin{array}{l}\text { Disagree \& Strongly } \\
\text { Disagree }\end{array}$ \\
\hline Accountant & 42.41176471 & 30.96732026 & 20.19607843 & 9.424837 \\
\hline Auditor & 20.58823529 & 15.03267974 & 9.803921569 & 4.575163 \\
\hline
\end{tabular}

Table - 17 Chi-Square Value

\begin{tabular}{|l|l|l|l|l|}
\hline Observed & Expected & $\mathrm{O}-\mathrm{E}=\mathrm{V}$ & $\mathrm{V} * \mathrm{~V}=\mathrm{X}$ & $\mathrm{X} / \mathrm{E}$ \\
\hline 53 & 42.41176471 & 10.58823529 & 112.1107 & 2.643387452 \\
\hline 32 & 30.96732026 & 1.032679739 & 1.066427 & 0.034437188 \\
\hline 8 & 20.19607843 & -12.19607843 & 148.7443 & 7.36501047 \\
\hline 10 & 9.424836601 & 0.575163399 & 0.330813 & 0.035100124 \\
\hline 10 & 20.58823529 & -10.58823529 & 112.1107 & 5.445378151 \\
\hline 14 & 15.03267974 & -1.032679739 & 1.066427 & 0.070940608 \\
\hline 22 & 9.803921569 & 12.19607843 & 148.7443 & 15.17192157 \\
\hline 4 & 4.575163399 & -0.575163399 & 0.330813 & 0.072306256 \\
\hline & & & Total & 30.83848182 \\
\hline
\end{tabular}

